\title{
Imagens das classes média e alta na história do cinema documentário brasileiro
}

\author{
Thales Vilela Lelo*
}

Resumo: Ao longo da história do cinema documentário no Brasil as classes média e alta da sociedade figuraram ou foram tema de filmes em circunstâncias bastante pontuais, tendo em conta a forte tendência da produção no país em centrar-se no "outro de classe". O objetivo deste artigo é identificar as principais formas de inscrição dessas camadas sociais na cinematografia nacional no período de 1967 a 2012.

Palavras-chave: história do cinema; documentário brasileiro; classes sociais; narrativas.

Resumen: A lo largo de la historia del cine documental en Brasil las clases media y alta de la sociedad han figurado o han sido tema de películas en circunstancias bastante puntuales, dada la fuerte tendencia de la producción del país a centrarse en el "otro de clase". El objetivo de este artículo es identificar las principales formas de inscripción de esas clases sociales en la cinematografía nacional en el período de 1967 a 2012. Palabras clave: historia del cine; documental brasileño; clases sociales; narrativas.

\begin{abstract}
Throughout the history of Brazilian documentary cinema, the middle and upper classes of society have been either present or the subject of films in very specific circumstances, given the strong tendency of production in the country to focus on the "class of the other". The aim of this article is to identify the main forms of inscription of these social classes in the national cinematography from 1967 to 2012.

Keywords: cinema history; Brazilian documentary; social classes; narratives.
\end{abstract}

Résumé : Tout au long de l'histoire du cinéma documentaire au Brésil les classes moyennes et supérieures de la société ont été ou ont fait l'objet de films dans des circonstances très particulières, compte tenu de la forte tendance de la production à se concentrer sur « l'autre classe ». L'objectif de cet article est d'identifier les principales formes d'inscription de ces classes sociales dans la cinématographie nationale de 1967 à 2012.

Mots-clés : histoire du cinema ; documentaire bresilien ; classes sociales ; recits.

* Universidade do Estado de Minas Gerais, Unidade Divinópolis, Cursos de Jornalismo, Publicidade e Propaganda. 35501-170, Divinópolis-Minas Gerais, Brasil. E-mail: thales.lelo@gmail.com

Submissão do artigo: 30 de janeiro de 2018. Notificação de aceitação: 20 de julho de 2018. 


\section{Introdução}

Parto de uma constatação: na trajetória da produção em cinema documentário no Brasil há uma sensível sub-representação das classes média e alta. Em uma das principais obras dedicadas a averiguar as construções cinematográficas da alteridade no documentário nacional, Bernardet (2003) debruça-se em produções do início dos anos de 1960 até o princípio da década de 1980, delineando, na esteira, a inclinação desses filmes em retratar o "outro de classe", seja ele migrante, operário, camponês, favelado, enfim, pertencente a um segmento populacional que não corresponde àquele da equipe de filmagem. A miséria e a injustiça as quais estas camadas sociais estavam submetidas ganharia visibilidade nas cenas e seria consequentemente denunciada na narrativa, buscando sensibilizar o espectador (potencialmente membro do mesmo segmento de classe do cineasta) às mazelas que infiltravam a idealizada imagem do Brasil "em desenvolvimento" construída pelos governantes da época.

Bernardet (2003) intitula essa tradição em cinema documentário (composta de filmes como Viramundo (1965), de Geraldo Sarno ou Maioria absoluta (1964-1966), de Leon Hirzman) de "modelo sociológico". Isto, pois, segundo o autor, nas obras afinadas a esse modelo, a voz em off do locutor (ou voz de Deus, segundo a terminologia de Nichols (1983)) era externa à experiência filmada e a configurava a partir de uma tese a ser defendida ao longo da narrativa. Os homens e as mulheres ordinários que compõem os planos desses documentários não vocalizam seus sofrimentos para além de suas próprias vivências. O lócus das inferências passíveis de generalização nas tramas é a própria locução em off, envolvida em verniz cientificista.

Das décadas de 1980 em diante, como já pontuaram Guimarães (2010) e Mesquita (2010) em outras oportunidades, promove-se um nítido deslocamento do modelo narrativo outrora hegemônico na produção brasileira, colocando em cheque a leitura sociológica dos problemas sociais e a representação generalizante do outro de classe (antes disposto como "objeto de estudo" nas obras). Uma postura ética reflexiva impõe uma particularização de enfoque em filmes do período (que têm como ilustração emblemática Cabra marcado para morrer (1964-1984), de Eduardo Coutinho), impelindo a uma singularização da alteridade através do corpo-a-corpo do cineasta com o mundo filmado, seja através da observação atenta das vivências que compõem a experiência cotidiana das pessoas comuns, seja por meio do estabelecimento de interlocuções mais horizontais entre a equipe e os personagens das tramas. No entanto, persiste uma ênfase em filmar o "outro de classe" - ainda que sua visibilidade não esteja diretamente atrelada a uma denúncia das injustiças sociais (uma vez 
que se questiona o "mandato popular" dos cineastas para falar "em nome" dos excluídos).

Ainda mais recentemente, sobretudo no contexto de emergência de uma nova classe média, originária do crescimento econômico e das políticas de redistribuição de renda empreendidas pelos governos Lula (2003-2010), despontam, timidamente, obras dedicadas a retratar o universo desse estrato da população, não sem problematizar eventuais tensões em jogo quando em contato com suas vivências. Concomitantemente, na perspectiva de Ramos (2014), inaugura-se um novo giro reflexivo na cinematografia documentária nacional, pavimentado pela paulatina desconstrução do lugar de enunciação conferido ao sujeito-da-câmera, ${ }^{1}$ sujeito este que, sensível às demandas éticas do seu tempo, assume-se consciente dos entraves à representação do outro ao mesmo passo em que passa a habitar a escritura fílmica enquanto personagem das tramas.

A despeito de essa recente figuração das classes média e alta na produção brasileira em cinema documentário ter sido correspondida por ensaios acadêmicos debruçados em apreender os elementos-chave que compõem os eixos narrativo, ético e estilístico de filmes específicos, há uma pronunciada ausência de esforços mais transversais, capazes de deslindar, em viés genealógico, tendências de inscrição desses segmentos da sociedade na escritura fílmica. O presente trabalho procura, na medida do possível, compensar esse déficit, apresentando, em paralelo à averiguação de um conjunto de documentários produzidos no Brasil do período de 1967 a 2012 (e das entrevistas concedidas por seus realizadores à crítica especializada), quatro modos de figuração das camadas médias e altas da população, tomando por referência os meios adotados pelo sujeito-da-câmera para estabelecer relações com esse "outro da mesma classe": a tipificação; a má consciência; o dispositivo; e o encontro. ${ }^{2}$

\section{Retratos tipificados}

Uma locução em off, ao estilo voz de Deus, pontua a narrativa de $A$ opinião pública (1967), longa metragem dirigido por Arnaldo Jabor - possivelmente o primeiro documentário a se deter na classe média brasileira, no período imediatamente posterior ao início do regime civil militar no país (que perdurou

1. Para Fernão Ramos (2008), o sujeito-da-câmera não se constitui propriamente como um indivíduo físico, mas como um ser que surge transfigurado pela câmera que o abriga junto de si (incorporando a máquina que sustenta com o corpo, mas também a equipe que o faz existir como imagem cinematográfica), fundando a tomada ao transformar a ação dos sujeitos no mundo em encenação.

2. 14 obras em curta, média e longa metragem foram escolhidas para compor o corpus de análise do presente trabalho, levando em conta sua adequação ao horizonte de análise (a lista completa acompanha as referências bibliográficas do artigo). 
de 1964 a 1985). Há uma inquietação que conduz a obra, como o seu diretor muito bem explicita: "Eu via que tinha acabado de acontecer um golpe militar em cima da classe média. Aquelas multidões de classe média (...) E a classe média, ninguém fala dela? Eu percebi que, no Brasil, a existência da classe média é essencial, é fundamental". ${ }^{3}$ Adiante, arremata: "Como é que aquelas pessoas individualizadas, formaram um conjunto, formaram multidões, que acabaram fazendo uma revolução contra eles mesmos? Toda a ingenuidade misturada com reacionarismo, com a falta de informação política da chamada classe média brasileira" ${ }^{4}$. Essas interrogações organizam uma tese mormente negativa sobre esse segmento da sociedade, retratado pelo documentário como uma massa alienada. Em determinado momento da trama, em meio às cenas em close up de membros das tais camadas médias da população brasileira, o locutor explicita o raciocínio que conduz a narrativa, já antecipado por seu diretor: "A classe média é uma classe perplexa. Não tem um sistema de valores criados por uma ação histórica dela mesma. São multidões de indivíduos solitários. Indivíduos iguais, que misteriosamente se julgam diferentes”.

A simpatia pelos explorados cede aqui lugar à rejeição de todo um estrato social, "o outro da mesma classe" o qual o sujeito-da-câmera procura se distanciar. As personagens selecionadas para compor a trama são fundamentalmente singularidades genéricas, extraídas de um dos principais redutos da classe média no Brasil: o bairro de Copacabana, localizado na cidade do Rio de Janeiro. Estudantes despreocupados com o futuro do país e imersos em um hedonismo frívolo, celebridades do star system midiático que absorvem os seus fãs para práticas consumistas, funcionários condescendentes com as jornadas que lhes são impostas, donas de casa cegas a quaisquer questões que extravasem o ambiente doméstico, turbas em êxtase em cerimônias religiosas e emitindo opiniões das mais absurdas quando indagadas sobre os "reais" problemas da nação... O retrato da classe média tecido em A opinião pública planifica eventuais contradições em benefício à tipificação do conjunto. $\mathrm{O}$ objetivo de Jabor era desvelar, por detrás da normalidade do cidadão pertencente a esse segmento da sociedade, um misto de exotismo e estranheza que tornaram essas pessoas facilmente manipuláveis na ocasião do golpe militar de 1964.

Na linha de Comolli (1995), seria possível alegar que a classe média tipificada de $A$ opinião pública é um inimigo pioneiramente representado pelas lentes de Jabor. Espera-se que o espectador, também proveniente dessas clas-

3. Trecho de entrevista com Arnaldo Jabor, disponível em: www.youtube.com/watch?v= VUAhXFVkc8A

4. Trecho de entrevista com Arnaldo Jabor, disponível em: www.youtube.com/watch?v= VUAhXFVkc8A 
ses, atormente-se pelo que vê e desperte sua consciência política, apartando-se da alienação que penetra tais camadas da sociedade. Segundo o diretor ${ }^{5}$, os espectadores veriam no filme um espelho partido de seu próprio comportamento. Mas tal recepção não é isenta de percalços, como sustenta Bernardet (2003) em sua análise do filme. Para o autor, se A opinião pública funciona em certa medida como um reflexo da experiência mundana do espectador, então não é só o rechaço o sentimento manifesto diante das imagens: as cenas também suscitam nossa identificação, pois compõem fragmentos de nosso cotidiano enquanto públicos de classe média. Na letra de Bernardet, "o cineasta exorciza a classe média e se fustiga por ser talvez um de seus membros" (2003: 68). Ademais, como Comolli (1995) elucida, para filmar o inimigo em um documentário é necessário entrar em relação com ele, gesto que pode minar a distância idealizada na narrativa: como não se comover diante da mãe solteira que, sozinha em seu apartamento, clama sem sucesso pela atenção da filha pequena? Mesmo que saibamos que essa mesma personagem era aquela que, no início do filme, compunha um trecho sobre a inércia da juventude (discursando fervorosamente em meio a um grupo de adolescentes acerca das diferenças entre amor e paixão), interrogamo-nos: o quão semelhante ela é aos nossos olhos, enquanto seus espectadores?

Dez anos mais tarde, um filão da produção documentária exibida no Globo Repórter, programa da Rede Globo diretamente influenciado pela linguagem televisiva e pelos procedimentos tecnológicos inovadores que adentraram nesse meio, também enfoca-se nos dilemas da classe média em algumas de suas produções, operando segundo o mesmo registro de tipificação desse segmento da população. Em Patroa X Empregada (1976), de Alberto Salvá, já no título promove-se um contraponto entre as donas de casa de uma emergente burguesia e suas empregadas domésticas. Conforme França et al (2011), as injustiças as quais estão submetidas estas são confrontadas com a futilidade daquelas: "Enquanto as domésticas aparecem lavando vasos sanitários, estendendo roupas no varal, penduradas nas janelas de enormes edifícios para lavar vidraças e descansando nas praças aos domingos, as patroas aparecem em salões de beleza, com rolinhos no cabelo, fazendo escova, falando o que pensam das empregadas" (França et al, 2011: 100-101). Nas entrevistas, a empatia do sujeito-da-câmera diante dos relatos das empregadas é criticamente espelhada pelo seu desprezo pelas "patroas" - que impunemente destilam preconceitos para a câmera de Salvá. Uma vez mais, o "outro da mesma classe" emerge

5. Trecho de entrevista com Arnaldo Jabor, disponível em: www.youtube.com/watch?v= VUAhXFVkc8A 
para o espectador como um inimigo em potencial, não obstante as ambivalências inerentes a essa forma de retratação da alteridade.

Já em Retrato de classe (1977), dirigido por Gregório Bacic, a classe média paulistana figura nas telas tomando por premissa a reunião de uma turma escolar, mais de 20 anos após a formatura (ocorrida em 1955). Uma fotografia amarelada dos estudantes é captada em primeiro plano percorrendo os rostos de cada uma das crianças, organizadas em torno da professora. No presente das filmagens, a docente, em narração em off subjetivada, tenta adivinhar os rumos que tomaram cada um de seus alunos. Vemos um a um encenar, em paralelo aos prognósticos da professora, suas vidas atuais, ao passo que seus típicos sonhos e anseios são revelados ao diretor por meio de entrevistas. Nessa miríade de rostos, chama atenção, como já bem assinalado por França et al. (2011), que a única aluna negra da turma (que se tornou empregada doméstica) tenha sido esquecida pela docente e parcialmente silenciada pela narrativa de Bacic: "ao contrário dos colegas, dela não se pergunta sobre os sonhos, as frustrações, os desejos, assim como não se solicita que encene o seu cotidiano para a câmera, como é feito com os outros personagens" (França et al., 2011: 103).

A tipificação por meio do contraste de classes é recurso adotado também em um documentário produzido três décadas após Retrato de Classe. Em Faixa de areia (2007), realizado pelas diretoras Daniela Kalmann e Flávia Lins e Silva, o fio condutor é a problematização da suposta "democracia" das praias cariocas (em tese responsáveis por diluírem as barreiras que apartam os segmentos da sociedade na metrópole). O filme paulatinamente desconstrói esse argumento na mesma medida em que cruza de uma praia a outra coletando depoimentos de públicos das mais variadas camadas sociais. Mais ou menos na metade do longa, salta aos olhos as declarações de alguns dos entrevistados provenientes das elites que, em um misto de preconceito e alienação (reverberando o espírito de $A$ opinião pública) escancaram sua repulsa à partilha do espaço urbano ou ainda naturalizam sem qualquer má consciência as segregações sociais, instigando o desconforto do espectador. Os jovens de Ipanema, "mauricinhos" e "patricinhas" nas palavras de um dos interlocutores das diretoras, são retratados como os garotos do filme de Jabor que diziam amar os domingos de sol e mar, alheios a qualquer preocupação crítica. Já no aterro do Flamengo, quando indagada sobre a presença de moradores de periferia na orla, uma banhista que nem mesmo é identificada nos créditos revela que julga desagradável ter de partilhar o espaço com eles, uma vez que, em suas palavras, tais pessoas seriam desprovidas de educação e valores morais.

Todavia, desde o lançamento de A opinião pública, a caracterização de uma camada da sociedade como antagonista só reincide com o mesmo teor 
crítico em Um lugar ao sol (2009), dirigido pelo cineasta Gabriel Mascaro. O filme começa com um close up de um catálogo com diversos nomes em letras garrafais. Na sequência, os créditos explicam do que se trata a enigmática lista e o dispositivo condutor do documentário: "Os personagens desse filme são moradores de valorizadas coberturas. O contato só foi possível a partir de um curioso livro que cataloga a elite e pessoas influentes no Brasil. $\mathrm{Na}$ lista, foram identificadas 125 coberturas. Apenas nove concordaram em ceder entrevista". Para o diretor, como exposto em entrevista concedida ao portal Esquerda Diário (2014), tratava-se inicialmente de explorar o imaginário das classes abastadas, escassamente abordadas pelo cinema brasileiro. Na mesma conversa, Mascaro também salienta que procurava não conferir um olhar sociológico para seus interlocutores, evitando uma figuração classista da elite ou sua caracterização como um "bloco de cimento homogêneo". Da mesma forma, também não se propunha a construir uma narrativa que operasse contra o que era dito pelos personagens.

A despeito das pronunciadas preocupações de Mascaro, o que transparece nas imagens é a mais cristalina tipificação dos moradores de coberturas. As conversas do diretor de Um lugar ao sol tomam como premissa a verticalização das cidades brasileiras e o status concedido aos residentes destes espaços, mas não avançam para um real encontro com as pessoas do outro lado da câmera porque há uma tese de fundo que sustenta o argumento do filme: morar no andar superior de prédios é, principalmente, uma questão de poder simbólico. Por essa razão, os temas debatidos permanecem no raio de alcance dessa tese (que é por vezes enunciada através das interrogações que o diretor dirige aos entrevistados), oferecendo uma caricatura ridícula e repulsiva das elites. Em meio às defesas fervorosas da meritocracia, preocupações absolutamente mesquinhas e racionalizações da desigualdade social, salpicam depoimentos como o de uma proprietária que celebra o fato de sua cobertura ter uma área de serviço apartada dos demais cômodos, garantindo assim maior "privacidade"; ou ainda um casal do Rio de Janeiro que discorre sobre a suposta falta de civilidade dos marginalizados; ou mesmo um empresário que defende, em tom jocoso, os privilégios concedidos aos mais ricos: "Eu vim ao mundo pelas coisas boas da vida, pelos prazeres bons da vida. Eu me sinto muito mal quando vejo um pobre que não tem Jaguar e que não tem Mercedes, desculpe a minha ironia”. À vista disso, não surpreende que Mascaro tenha confessado (na entrevista concedida para o portal Esquerda Diário (2014)), que não teria conseguido acessar o grupo social que pretendia. $\mathrm{O}$ enfoque nas distâncias que $\mathrm{o}$ separam dos habitantes das coberturas lhe permite encará-los como caricaturas das assimetrias de classe enraizadas na sociedade brasileira. 


\section{Narrativas da má-consciência}

Conforme mencionado na introdução, a produção em cinema documentário no Brasil vivenciou nas últimas décadas um giro em sua postura ética diante dos sujeitos filmados, influenciada sobremaneira pelas reflexões do pósestruturalismo (Ramos, 2008). O sujeito-da-câmera passa a adotar uma atitude reflexiva, assumindo deliberadamente seu lugar de enunciador em corpo-acorpo com o mundo captado pela câmera. A explicitação da dimensão discursiva ocupa o espaço antes preenchido pelas representações totalizantes que embasavam argumentos sociológicos ilustrados pelas imagens de homens e mulheres ordinários. Em síntese: o documentário adere a um dispositivo discursivo que se fundamenta na confissão, via narrativa, de suas próprias condições de enunciação. Por este esteio, as figurações generalizantes da alteridade são acidamente criticadas pelo espírito ético em vigor. Uma "má consciência" aflora entre muitos diretores que decidem revelar, em suas tramas, o universo de valores encoberto que permeava seu acesso ao mundo social. Um traço formal deste processo, evidenciado por Brasil (2013), é a exposição do antecampo na escritura fílmica, dispondo a equipe de produção na cena. Segundo o autor, a representação clássica (de objetivação do olhar pela câmera) é cindida em consequência, promovendo uma relação de "mútua implicação e alteração entre quem filma e quem é filmado, entre mundo vivido (extradiegético) e mundo fílmico (diegético)" (Brasil, 2013: 579).

Exaustivamente analisado pela literatura acadêmica em anos subsequentes ao seu lançamento (Mesquita, 2010; Ramos, 2014; Feldman, 2014), Santiago (2007), dirigido por João Moreira Salles, afina-se a este "espírito do tempo": na obra, o diretor recupera um projeto inconcluso, interrompido em 1992, de documentar as memórias de Santiago, mordomo da família Salles por 30 anos. Na retomada, ocorrida mais de 10 anos após o encerramento dessas filmagens iniciais (e embalada pelo fato do personagem ter falecido em 1994), Salles tem como fio condutor uma autocrítica à sua má consciência enquanto cineasta no período em que dirigiu o primeiro Santiago: "Dirigi alguém na tentativa de fazer com que essa pessoa ficasse mais parecida com o personagem que eu julgava ser o verdadeiro Santiago. Olha só a quantidade de enganos, a começar pela ilusão de que existe a pessoa verdadeira, inequívoca" (Salles apud Oricchio, 2009). O segundo Santiago é, sobretudo, uma reflexão sobre o material bruto, revelando como, nas filmagens de 1992, a figuração de Santiago estava limitada tanto pelo engessamento dos papeis de cineasta e personagem construído para a narrativa (o "verdadeiro" Santiago que deveria se materializar no filme) quanto pela relação hierárquica que Salles possuía com seu interlocutor. Em certo ponto da trama, em locução em off, o diretor mesmo confessa: 
"Durante os cinco dias de filmagem, eu nunca deixei de ser o filho do dono da casa, e ele nunca deixou de ser o nosso mordomo".

Por meio de uma "estética do fracasso", na oportuna conceituação de Feldman (2014), Santiago é um documentário pontuado pelas bordas do material de 1992, que, segundo Salles (em entrevista ao Estadão (2009)), expõe a exata relação do cineasta com o personagem. O autoritarismo das primeiras gravações é sobreposto à problematização ética da encenação clássica no documentário e das assimetrias de classe no Brasil, naturalizadas no projeto inicial. Em uma espécie de "alter-biografia" (Mesquita, 2010), Salles comenta, no presente, o seu lugar no primeiro Santiago (enquanto membro de uma família abastada, enquanto antigo patrão do personagem, enquanto diretor insensível à presença do outro). Distintamente das obras elencadas na seção anterior, que se distanciam da alteridade (no caso, as classes média e alta) ao se colocarem diante dela (devido a um conjunto de premissas engessadas sobre esses segmentos da população que impregnam a narrativa fílmica), em Santiago a aproximação (como relação possível) se dá pela distância temporal e pelo reconhecimento dos entraves que cercearam um genuíno diálogo.

Babás (2010), curta-metragem realizado por Consuelo Lins, caminha em curso análogo. A diretora discorre sobre as relações entre patrões e empregadas domésticas pelo filtro de sua própria experiência como alguém que pertence a um estrato privilegiado da sociedade que goza da possibilidade de contratar babás para auxiliar na criação dos filhos. Lins é mobilizada não só pelo interesse em retratar as opressivas relações de classe que configuram o trabalho doméstico no país (remontando à época da escravidão), mas também por certo desejo de "elaboração de uma dívida, de reparo de um dano" (Mesquita e Souto, 2015: 46), que obscureceu o protagonismo dessas mulheres em sua vida. Dotado de pronunciada carga subjetiva (tal qual Santiago), Babás constrói uma interlocução possível a partir da distância de classe estabelecida entre a cineasta e suas personagens, imprimindo nas imagens notável ambivalência: ao mesmo tempo em que cria um sensível espaço de escuta para suas interlocutoras, a cineasta coreografa-as em algumas cenas de maneira quase ficcional, ordenando-as em posturas e enquadramentos rígidos que transparecem afastamentos que extravasam as boas intenções manifestas na narrativa.

\section{Dispositivos de conexão}

Outra forma de figuração das classes média e alta no cinema documentário brasileiro - também sintonizada à estilística moderna e às inclinações éticas contemporâneas - é por meio da instauração de dispositivos que presidem o contato como o mundo social e a própria captação de imagens, muitas vezes 
obtidas sem a presença direta da equipe de filmagem e moduladas na montagem, pelos cineastas. Tais filmes vêm sendo apreendidos como "etnografias discretas" (Feldman, 2012), por criarem estratégias de partilha por meio do recolhimento da enunciação fílmica, valendo-se de gravações obtidas do interior de relações pré-existentes aos interesses do documentário, e inserindo o diretor, no processo, como mediador de uma distância estabelecida entre ele e seus interlocutores.

Rua de mão dupla (2004), realizado por Cao Guimarães (e concebido inicialmente como videoinstalação), é organizado pelas filmagens de seis moradores solitários pertencentes às classes médias da cidade de Belo Horizonte, em Minas Gerais. Por solicitação do diretor, os participantes do projeto se dividiram em três duplas e trocaram de residência por 24 horas. Na casa de outrem, poderiam gravar o que lhes aprouvesse, buscando identificar, nos objetos e móveis da habitação alheia, traços da personalidade de seu proprietário. Ao final do dia, concederiam à câmera um depoimento sobre suas vivências no espaço e sobre a "imagem mental" que construíram de seu colega desconhecido. Guimarães posteriormente editou o material bruto coletado e o dividiu em três blocos (um para cada dupla), dispostos no filme em trechos de 25 minutos em média. Como apontam Lins e Mesquita (2008), o objetivo do dispositivo criado é suscitar que os personagens discorram sobre si mesmos a partir do olhar que tecem sobre o outro, expondo o universo de valores que norteia sua inserção na residência alheia. $\mathrm{O}$ isolamento de cidadãos de grandes centros urbanos emerge nos depoimentos dos envolvidos no "jogo" mesclado a visível dificuldade de se acomodarem no espaço alheio.

Pacific (2009) e Câmara escura (2012) de Marcelo Pedroso, também constroem dispositivos para obtenção de imagens de sujeitos oriundos das camadas médias e altas da população sem que tenham que participar diretamente do processo, restringindo a direção ao papel da montagem. Pacific é composto pela montagem de imagens amadoras captadas por turistas que fizeram uma viagem no cruzeiro Pacific (que parte do porto de Recife rumo ao arquipélago de Fernando de Noronha) e posteriormente cederam suas gravações pessoais para a equipe do diretor (que nunca esteve pessoalmente no navio). Uma vez que os pedidos eram feitos quando as imagens já haviam sido captadas, havia um interesse, da parte de Pedroso, de obter gravações que inicialmente não estavam direcionadas à composição de um filme (distintamente de Rua de mão dupla). O diretor propunha construir seu olhar sobre o cruzeiro a partir dos gestos fabulatórios espontâneos dos turistas. Ecoa aqui uma discussão de Comolli (2008) sobre a crescente preocupação com a imagem na contemporaneidade, posto que há uma profusão de câmeras portáteis e dispositivos de 
visualização que obrigam os sujeitos a produzirem ininterruptamente mise-enscènes de si mesmos como forma de regular a composição de sua imagem para eventuais públicos. Em entrevista ao portal Cinética, Pedroso comenta essa premissa de sustentação de Pacific: "A apropriação que os personagens têm da linguagem cinematográfica, jornalística ou documental nos permite criar essas pontes. Não são imagens puras e brutas que correspondam a um estado virgem de um olhar, mas imagens que já vêm contaminadas por esses princípios" (Pedroso apud Guimarães, 2013).

Mas em Pacific também há um projeto crítico, como confessa Pedroso em uma troca de mensagens com Jean-Claude Bernardet transcorrida em 2010 (e posteriormente publicada no blog do crítico). ${ }^{6} \mathrm{O}$ cineasta procurava problematizar a colonização das reservas de imaginação pelo capitalismo contemporâneo (que investe na "gestão da vida" e dos ideais de felicidade, como argumenta Brasil (2010), bem como a hiperatividade que consome o suposto tempo de descanso dos turistas na embarcação por meio de uma sucessão de ações lúdicas (jantares, aulas de ginástica, festas ao ar livre devidamente coreografadas) e a inclinação dos viajantes em validar suas experiências através de seu registro em imagens (como a exemplo das pessoas que, logo no início do filme, ao captarem com as câmeras os golfinhos cruzando o navio, atestam: "Agora valeu!", e ainda, em tom jocoso, “já ia pedir meu dinheiro de volta!"). Todavia, distintamente do que ocorrera nas obras que figuravam a classe média de um prisma generalizante, não há na montagem aqui um esforço em trabalhar contra seus personagens, sintetizando-os em um argumento cáustico que poderia, a título de ilustração, classificar a viagem em cruzeiro como um espetáculo alienante de uma classe inerte. Pedroso desenvolve um olhar compreensivo para essa alteridade no gesto de se reconhecer nela, como confidencia à Bernardet: "as imagens me enterneceram e eu passei a reconhecer ali, naquele imaginário extasiado, elementos que dizem respeito à nossa própria constituição enquanto pessoas, a aspectos os mais frágeis de nossa formação" 7 . Há uma "distância justa" esculpida na montagem (Brasil, 2010; Feldman, 2012), que não adere acriticamente ao mundo filmado ao mesmo passo em que evita depreciar a excepcionalidade das férias que desfrutam os passageiros do Pacific. Conforme nos interroga Pedroso, "Isso é um momento de exceção na vida deles [os turistas]. Não seria presunçoso julgá-los? E o quanto de nós mesmo há ali dentro?" (2010).

A preocupação com a imagem é também alicerce de composição do curtametragem Câmara escura, mas em sentido inverso ao explorado em Pacific:

6. Disponível em: http://jcbernardet.blog.uol.com.br/arch2011-01-09_2011-01-15.html

7. Disponível em: http://jcbernardet.blog.uol.com.br/arch2011-01-09_2011-01-15.html 
na obra, o cineasta propõe um dispositivo capaz de instigar a paranoia de moradores de classes altas de terem imagens do seu espaço domiciliar obtidas à revelia de sua autorização prévia. Instalando na porta de residências de alto padrão uma caixa com uma câmera ligada, Pedroso assiste os residentes levarem o aparelho para dentro de suas casas enquanto fabulam as razões para o experimento: seria uma estratégia de ladrões ansiosos por coletarem imagens do interior dos imóveis? O diretor retorna às residências posteriormente e recolhe o objeto, montando sua obra articulando sentimentos que permeiam a experiência mundana em grandes centros urbanos, a exemplo da excessiva desconfiança diante do desconhecido.

Uma última obra alinhada a esse modo de retratação das camadas médias e altas da população brasileira por meio da construção de dispositivos também se infiltra, mormente, no espaço doméstico de famílias de significativo poder aquisitivo, muito embora, nesse caso, haja anuência prévia dos envolvidos. Doméstica (2012), realizado por Gabriel Mascaro, tematiza, assim como Santiago e Babás, as dimensões de classe impressas nas relações entre patrões e empregadas domésticas. A diferença, nesse caso, é que o filme de Mascaro não se baseia nas inflexões subjetivas do diretor, mas em um mecanismo similar ao empregado por Cao Guimarães em Rua de mão dupla: o cineasta entrega a set jovens câmeras portáteis para que possam gravar os afazeres cotidianos de suas funcionárias em seus lares. O longa é composto de trechos dessas filmagens posteriormente editadas por Mascaro.

A decisão de atribuir a câmera para os adolescentes não é casual, entretanto. Segundo o cineasta, em entrevista para o portal Esquerda diário, o objetivo com o dispositivo era suscitar uma inversão do olhar desses jovens, que deveriam "por uma semana observar a pessoa que, em muitos casos, os observou pela vida inteira. E nesta semana de redescoberta do olhar, proporcionar uma renegociação de papeis" (Mascaro apud Diário, 2014). Mascaro afina sua mirada adentrando em um universo íntimo de relações que preexistia ao momento das gravações, mas que adquire novas nuances com a presença da câmera. Como alerta o diretor, há um misto de afeto e autoridade na maior parcela dos blocos que compõem a obra, uma vez que muitos dos adolescentes foram criados desde pequenos por aquelas mulheres (e homens, já que há um empregado entre os personagens), mas também estão se afirmando como patrões - além de deterem a câmera, que lhes outorga um poder adicional de selecionarem quais imagens captar. A despeito de o documentário construir uma visão crítica sobre muitas das relações filmadas (percebe-se nitidamente a opressão e a condição de precariedade a qual muitas das trabalhadoras estão submetidas, ainda que os patrões aleguem que elas são "parte da família"), 
não generaliza as situações apresentadas segundo um modelo sociológico das desigualdades. Há uma ambivalência que permeia a obra e não nos permite, enquanto espectadores, concluir se o dispositivo tão somente prolongou as relações de subordinação pré-existentes ou "se as empregadas usaram este artifício audiovisual na relação para se autoficcionalizar" (Mascaro apud Diário, 2014), elemento que complexifica a narrativa em detrimento da confirmação de hipóteses extra fílmicas (como ocorrera em Um lugar ao sol, do mesmo diretor).

\section{Figuras do encontro}

Uma última forma de figuração das classes média e alta no cinema documentário brasileiro ancora-se no engajamento do cineasta pela ocasião de sua interação com os sujeitos que compõem as narrativas. Assim como nas obras elencadas nas duas últimas seções, há uma forte sintonia com a orientação ética que vigora contemporaneamente, de cunho participativo-reflexivo, mas aqui ela não é acionada para proporcionar o recuo do enunciador ou sua total impregnação na escritura fílmica (dotando toda obra de tonalidades autobiográficas). Aposta-se na capacidade do cinema de edificar situações de diálogo singulares, que não se reduzem a uma aceitação resignada do mundo ou à sua completa negação em benefício a uma tese que precede à circunstância da tomada.

Exemplo significativo dessa tendência é o filme Pro dia nascer feliz (2006), com direção de João Jardim. O documentário é construído a partir de depoimentos de estudantes e professores provenientes de instituições de ensino de diferentes Estados brasileiros (de rede pública e privada), instituições estas habitadas por pessoas oriundas de classes sociais díspares. Embora os relatos gravitem em torno dos mesmos eixos temáticos (vivência e sofrimento no ambiente escolar, projetos de vida e inquietações a respeito do mundo social), há um nítido contraste de classes destacado pela obra, sobretudo quando dispõe em sequência histórias de jovens alocados em instituições sem quaisquer condições de infraestrutura, enquanto outros são retratados circulando por corredores e salas de arquitetura moderna, com aulas dos mais variados temas (preparadas especialmente para a realização dos processos seletivos para admissão em universidades). Inclusive há um trecho em Pro dia nascer feliz em que um conjunto de estudantes do colégio particular conversa com o diretor sobre o fato de se manterem apartados do convívio com os segmentos da população mais carentes, vivendo em uma espécie de "bolha social" (a qual muitos revelam completo desinteresse em romper). Mas antes que possamos nutrir antipatia por esses adolescentes ou mesmo cimenta-los em uma totali- 
dade genérica ("o jovem de classe média", como enunciava o locutor em off de A opinião pública), somos em seguida apresentados aos seus dramas particulares, como a pressão incessante que sofrem para obterem resultados exemplares, atendendo as expectativas daqueles à sua volta. Os personagens antes enquadrados como um grupo são então singularizados na narrativa, adensando o quadro delineado pelo diretor.

Mas no que tange à elaboração de uma poética do encontro como método de filmagem, o diretor Eduardo Coutinho é expoente central por desenvolver uma estilística totalmente afinada às demandas por reflexividade que impregnaram a discussão ética contemporaneamente. Em dois filmes de sua extensa filmografia, Theodorico, o Imperador do Sertão (1978) (exibido como reportagem especial para o Globo Repórter no mesmo período histórico em que foram produzidos Patroa X Empregada e Retrato de classe) e Edifício Master (2002), o cineasta teve como interlocutores privilegiados sujeitos pertencentes à elite rural e à classe média baixa, respectivamente. Mas o recorte por segmento social nesse caso opera exclusivamente para restringir o universo fílmico, uma vez que o diretor não procura oferecer uma síntese das visões de mundo de seus personagens: "eu tento desconsiderar o problema da classe ou da categoria à qual a pessoa pertence e fazer filmes que não sejam estereótipos" (Coutinho apud Frochtengarten, 2009: 134). Isto, pois, novamente segundo Coutinho, “quando você reduz uma pessoa ao 'típico', quando você objetiva uma pessoa, coloca intencionalidade na abordagem, você mata toda possibilidade de ter um personagem rico, surpreendente" (Coutinho apud Figuerôa et al, 2003: 227).

O que interessa ao diretor, como já pontuado por Xavier (2004) e Lins (2004), é a singularidade das vivências do outro, e não sua inscrição típica em um segmento dado por meio das opiniões que emite sobre assuntos gerais (a exemplo das entrevistas que compõe o bloco final de A opinião pública, em que a locução em off interroga transeuntes acerca de suas visões de mundo enquanto membros da classe média). Em Edifício Master, a circunscrição espacial é um edifício localizado no bairro de Copacabana, na cidade do Rio de Janeiro, composto de 276 apartamentos distribuídos em 12 andares. Interrogado em uma entrevista sobre o enquadramento temático do projeto, Coutinho é enfático: "O filme é sobre pessoas singulares que moram num prédio, e que eventualmente são da classe média. Ao classificar as pessoas, você começa a objetivar o outro, tomá-lo como emblema de alguma coisa. Aí é sociologia, é a morte desse tipo de cinema. Equivale a um assassinato simbólico da pessoa" (Coutinho apud Mattos, 2003: 103). A narrativa é composta de 37 conversas entre o cineasta e seus interlocutores, nas quais há uma inclinação metódica para o presente das filmagens enquanto catalisador de acontecimentos relevan- 
tes, como o caso da professora de inglês que confessa sua fobia social para a câmera ou ainda a garota de programa que afirma que só será feliz quando morrer (apesar de amar a vida) e mesmo um senhor aposentado que entoa, emocionado, a letra de My Way. Sem que haja qual orientação explícita de Coutinho, alguns temas são recorrentes em Edíficio Master, como a solidão que experimentam moradores de grandes conjuntos habitacionais, uma ânsia em serem ouvidos (possivelmente no ímpeto de saírem do isolamento que os cerca), o medo de muitos de exporem a própria imagem e a pouca riqueza vocabular presente nas conversas, que no mais das vezes não ultrapassam seis minutos de duração no longa. Em alguns casos o diretor confronta os personagens, suscitando questões que acionam um relato vívido, sem, todavia, resvalar em um absoluto distanciamento crítico. Conforme Xavier, Edifício Master "se faz para evidenciar que as pessoas são mais do que aparentam, e não menos, e podem atrair um interesse insuspeitado pelo que dizem e fazem, e não apenas pelo que representam ou ilustram na escala social e no contexto da cultura" (Xavier, 2004:186).

Já em Theodorico, o Imperador do Sertão, somos apresentados ao Major Theodorico Bezerra, integrante da elite rural brasileira, fazendeiro e político desde os anos de 1940, e em 1978 eleito deputado estadual pelo Rio Grande do Norte. O personagem formou currais eleitores na região em que exercera influência, fundou municípios, represou verbas públicas em benefício às suas terras e controlou as vidas daqueles que residiram em seus domínios. De saída, uma questão formulada na análise de Um lugar ao sol reincide aqui: como filmar o inimigo? Em entrevista a Carlos Mattos (2003), Coutinho lembra que, quando fora convidado para o projeto, recebeu a orientação de emular um sotaque nordestino para se aproximar do coronel, algo que prontamente recusou, já que em sua metodologia de trabalho resguardar as distâncias entre ele e seu interlocutor era fundamental. Logo no início das filmagens, o cineasta percebe o constrangimento que o coronel exercia sobre os camponeses que residiam na região, uma vez que acompanhava pessoalmente as filmagens e em pouco tempo passou a também formular questões interpelativas para os moradores, assumindo a função de entrevistador. Ao invés de interromper as gravações, Coutinho divide cordialmente a cena com Theodorico, registrando a intimidação gerada por sua excessiva presença no filme. Na montagem, não transparece cumplicidade com o coronel (que pensava que o documentário tratava-se de uma propaganda de sua trajetória política) e muito menos uma inscrição de sua mise-en-scène como maquiavélica ou caricata. $\mathrm{O}$ cineasta permite que o coronel protagonize a obra como deseja, expressando suas razões e sua visão de mundo, muito embora nos gestos e feições apáticas dos seus funcio- 
nários fique patente o poder opressivo exercido por ele sobre aquelas pessoas. Theodorico compõe, em sua própria mise-en-scène, uma singular figuração do coronelismo brasileiro, um "inimigo" que inspira nossa consciência crítica ao mesmo passo que se avizinha de nós em sua cômica artificialidade diante da câmera.

\section{Considerações finais}

No percurso estabelecido ao longo deste texto, privilegiou-se a apresentação de um contingente significativo de obras no intuito de evidenciar as formas de inscrição das classes média e alta adotadas pelo cinema documentário brasileiro ao longo da história. Embora não explicitado até aqui, é importante afirmar que as categorias formuladas não expressam um sentido de "evolução" histórica dos modos de representação desses segmentos da população na cinematografia nacional. Tratam-se, antes de tudo, de operadores analíticos acionados para escrutinar elementos de composição da linguagem e estilística que diferenciam as obras em seus modos de tematização de tais grupos sociais.

A classificação empregada também não deve ser lida em sentido hierárquico, como se as formas de figuração da alteridade afinadas a certo "modelo sociológico" estejam em nocivo descompasso com aquelas que explicitam suas instâncias de enunciação por meio de uma "má consciência" ou de um dispositivo participativo-reflexivo. Uma leitura que operasse por esse viés correria o risco, como já diagnosticado por Ramos (2008), de exigir dos filmes uma integral sintonia com o "espírito ético" do presente, descontextualizando suas intenções quando produzidos e as demandas de ordem estética e política que atendiam.

Olhar para as imagens das classes médias e alta no cinema documentário realizado no Brasil é perceber, sobretudo, os esforços dos diretores de se colocarem diante de um "outro da mesma classe", uma alteridade próxima de suas experiências mundanas e de seu universo de valores (uma vez que uma parcela substancial desses cineastas é proveniente dessas mesmas camadas socais), e que por essa mesma razão sensibiliza uma postura ambivalente: seriam esses outros nosso reflexo ou um signo daquilo que tanto procuramos nos distanciar?

\section{Referências bibliográficas}

Bernardet, J-C. (2003). Cineastas e imagens do povo. São Paulo: Companhia das Letras.

Brasil, A. (2010). Pacific: o navio, a dobra do filme. Devires, 7(2), 56-69. 
Brasil, A. (2013). Formas do antecampo: performatividade no documentário brasileiro contemporâneo. Famecos, 20(3), 578-602.

Comolli, J-L. (1995). ¿Mi enemigo preferido?. Cuadernos de cine documental, 2, 44-51.

Comolli, J-L. (2008). Ver e poder - A inocência perdida: cinema, televisão, ficção, documentário. Belo Horizonte: Editora Ufmg.

Diário, E. (2014). Gabriel Mascaro fala sobre seus filmes. Disponível em: www.esquerdadiario.com.br/spip.php?page=gacetillaarticulo\&id_article $=89$

França, A.; Habert, A. \& Pereira, M. (2011). Dispor e recompor: o documentário sob o gesto da montagem. Devires, 8(2), 94-109.

Feldman, I. (2012). "Um filme de": dinâmicas de inclusão do olhar do outro na cena documental. Devires, 9(1), 50-65.

Feldman, I. (2014). O fracasso como produção: sobre o documentário brasileiro contemporâneo. In C. Duncker \& A. Rodrigues (orgs.), Cinema e psicanálise (pp.145-164). São Paulo: nVersos.

Figuerôa, A.; Bezerra, C. \& Fechine, Y. (2003). O documentário como encontro: entrevista com o cineasta Eduardo Coutinho. Galáxia, 6, 213-229.

Frochtengarten, F. (2009). A entrevista como método: uma conversa com Eduardo Coutinho. Psicologia USP, 20(1), 125-138.

Guimarães, C. (2010). Comum, ordinário, popular: figuras da alteridade no documentário brasileiro contemporâneo. In C. Migliorin (org.), Ensaios no real (pp.181-197). Rio de Janeiro: Beco do Azougue.

Guimarães, V. (2013). Conversa com Gabriel Mascaro e Marcelo Pedroso. Disponível em: http://revistacinetica.com.br/home/conversacomgabrielmascaroemarcelopedroso/

Lins, C. (2004). O documentário de Eduardo Coutinho: televisão, cinema e vídeo. Rio de Janeiro: Jorge Zahar.

Lins, C. \& Mesquita, C. (2008). Filmar o real: sobre o documentário brasileiro contemporâneo. Rio de Janeiro: Jorge Zahar.

Mattos, C. (2003). Eduardo Coutinho: o homem que caiu na real. Portugal: Festival de Cinema Luso-Brasileiro de Santa Maria da Feira.

Mesquita, C. (2010). Retratos em diálogo: notas sobre o documentário brasileiro recente. Novos Estudos CEBRAP, 86, 104-119.

Mesquita, C. \& Souto, M. (2009) Doméstica: retrato, ponto de vista e posições de classe no cinema documental. In R. Veiga, C. Guimarães \& C. Maia 
(orgs.), Limiar e partilha: uma experiência com filmes brasileiros (pp.3871). Belo Horizonte: PPGCOM Ufmg.

Nichols, B. (1983). The voice of documentary. Film Quarterly, 36(3), 17-30.

Oricchio, L. (2009). Santiago: uma entrevista com João Moreira Salles. Disponível em: http://cultura.estadao.com.br/blogs/luiz-zanin/title-519/

Ramos, F. (2008). Mas afinal... o que é mesmo documentário?. São Paulo: Editora Senac.

Ramos, F. (2014). La mise-en-scène del documental: performance y procedimientos de actuación. Toma Uno, 3, 29-48.

Xavier, I. (2004). Indagações em torno de Eduardo Coutinho e seu diálogo com a tradição moderna. Comunicação e Informação, 7(2), 180-187.

\section{Filmografia}

A Opinião Pública (1967), de Arnaldo Jabor.

Patroa X Empregada (1976), de Alberto Salvá.

Retrato de Classe (1977), de Gregório Bacic.

Theodorico, Imperador do Sertão (1978), de Eduardo Coutinho.

Edifício Master (2002), de Eduardo Coutinho.

Rua de mão dupla (2004), de Cao Guimarães.

Pro dia nascer feliz (2006), de João Jardim.

Santiago (2007), de João Moreira Salles.

Faixa de Areia (2007), de Daniela Kallman e Flávia Lins e Silva.

Um lugar ao sol (2009), de Gabriel Mascaro.

Pacific (2009), de Marcelo Pedroso.

Babás (2010), de Consuelo Lins.

Doméstica (2012), de Gabriel Mascaro.

Câmara Escura (2012), de Marcelo Pedroso. 